\title{
ASPEK KEHANGATAN DAN KEPERCAYAAN DALAM KUALITAS KELEKATAN ANAK DENGAN PENGASUH DI LEMBAGA KESEJAHTERAAN SOSIAL ANAK (LKSA) ALKAUTSAR LEMBANG KABUPATEN BANDUNG BARAT
}

\author{
Mu'alimatus Sholihah \\ Politeknik Kesejahteraan Sosial Bandung, Jl. Ir. H. Juanda No. 367, Dago, Bandung \\ 40135, mualimatuss@gmail.com
}

Meiti Subardhini

Politeknik Kesejahteraan Sosial Bandung, Jl. Ir. H. Juanda No. 367, Dago, Bandung 40135, meitisubardhini@poltekesos.ac.id

\section{Denti Kardeti}

Politeknik Kesejahteraan Sosial Bandung, Jl. Ir. H. Juanda No. 367, Dago, Bandung 40135, dentikardeti@gmail.com

\begin{abstract}
Attachment refers to a relationship or emotional bonding that last for a long time, intertwined between individuals and attachment figures that are characterized by a desire to seek and maintain closeness to the attachment figures, especially in pressure time. This research aims to gain the empirical description about warmth and trust of children to caregivers. The method in this research uses descriptive method with a quantitative approach. Sampling in this research is census, and data collection technique uses: 1) questionnaire, 2) interview, 3) obervation, and 4) documentation study. As for the measuring instrument validity test uses face validity. Furthermore, the result analysed through quantitative and qualitative analysis.The result shows that The Attachment Quality of Children to Caregivers in Al Kautsar's Children Welfare Institution Lembang, West Bandung Regency is in moderate category. The result shows that The Attachment Quality of Children to Caregivers in Al Kautsar's Children Welfare Institution Lembang, West Bandung Regency is in moderate category. Therefore educational activities and fun discussions (Education and Fun Sharing) are needed to improve the quality of children's attachment to caregivers.
\end{abstract}

Keywords:

Attachment; Children; Caregivers

\begin{abstract}
Abstrak
Kualitas kelekatan (attachment) merujuk pada hubungan atau ikatan emosional yang bertahan dalam waktu yang lama, terjalin antara individu dengan figur lekatnya yang ditandai adanya keinginan untuk mencari dan memelihara kedekatan dengan figur lekat tersebut terutama pada saat-saat yang menekan. Penelitian ini bertujuan untuk mendapatkan gambaran empiris tentang kehangatan (warmth) dan kepercayaan (trust) anak dengan pengasuh. Metode penelitian yang digunakan dalam penelitian adalah
\end{abstract}


metode kuantitatif dengan pendekatan deskriptif. Teknik penarikan sampel dalam penelitian ini adalah sensus, yaitu dengan jumlah responden sebanyak 38 anak. Teknik pengumpulan data yang digunakan adalah: 1) kuesioner, 2) wawancara tidak terstuktur, 3) observasi, dan 4) studi dokumentasi. Adapun uji validitas alat ukur menggunakan validitas muka (face validity). Selanjutnya hasil penelitian dianalisis menggunakan teknik analisa data statistik deskriptif. Hasil penelitian menunjukkan bahwa kualitas kelekatan anak dengan pengasuh di Lembaga Kesejahteraan Sosial Anak Al Kautsar Lembang Kabupaten Bandung Barat termasuk dalam kategori sedang. Begitu pula pada semua aspek dalam kualitas kelekatan termasuk dalam kategori sedang. Maka dari itu kegiatan edukasi dan diskusi yang menyenangkan (Education and Fun Sharing) diperlukan upaya peningkatan kualitas kelekatan anak dengan pengasuh.

Kata Kunci:

Kelekatan; Anak-anak; Pengasuh 


\section{PENDAHULUAN}

Anak merupakan cita-cita perjuangan bangsa sekaligus sebagai sumber daya manusia di masa depan yang menentukan generasi mendatang. Desmita (2013) mengatakan bahwa masa anak merupakan masa yang terpanjang dalam rentang kehidupan saat dimana individu relatif tidak berdaya dan bergantung pada orang lain. Anak bukan orang dewasa dalam ukuran mini karena anak memiliki taraf dan pencapaian perkembangan tersendiri, sehingga anak harus memperoleh perlakuan yang tepat sesuai dengan perkembangannya (Christiana Hari Soetjiningsih, 2012). Kualitas perkembangan dan pertumbuhan anak yang baik akan menentukan masa depan yang baik pula untuk anak (Sri Lestari, 2016). Sayangnya, tidak semua anak mempunyai kesempatan yang sama, banyak diantara mereka yang beresiko tinggi untuk tidak tumbuh dan berkembang secara sehat. Anak-anak tersebut juga tidak terpenuhi kebutuhan mereka secara utuh, seperti halnya kebutuhan akan nutrisi yang tepat, pendidikan yang terbaik, serta kasih sayang yang cukup dan juga kebutuhan akan kelekatan (Abu Huraerah, 2018).

Kelekatan menurut Christiana Hari Soetjiningsih (2012:154) adalah "kecenderungan dan keinginan seseorang untuk mencari kedekatan dengan orang lain dan mencari kepuasan dalam hubungan dengan orang lain tersebut." Sedangkan kelekatan menurut Bowlby dalam Geldard, K. \& David, G. (2011:31) yaitu:

"Bahwa kelekatan atau kemelekatan adalah ikatan afeksional kekal yang memiliki suatu biologis vital yang sangat dibutuhkan untuk bertahan hidup dan bahwa hubungan antara seorang anak dan figur kemelakatannya menyediakan suatu fondasi kokoh yang akan digunakannya untuk mengeksplorasi dan menguasai dunia”.

Kemudiann Bowlby mengemukakan bahwa pola kelekatan terbagi ke dalam tiga pola yaitu pola secure attachment/aman, pola resistant attachment/cemas dan pola avoidant attachment/ menghindar. Individu yang mendapatkan secure attachment akan percaya diri, optimis, serta mampu membina hubungan dekat dengan orang lain, sedangkan apabila anak mendapatkan pola kelekatan yang lain, anak akan kesulitan untuk percaya diri dan tidak mampu berhubungan dengan orang lain. Menurut Chen dalam Sri Lestari (2016) kualitas kelekatan yang terjalin antara anak dengan figur lekat dapat diukur dengan beberapa aspek yaitu kehangatan (warmth), rasa aman (secure), kepercayaan (trust), afeksi positif (positive affect), dan ketanggapan (responsiveness). Kelekatan bisa didapatkan anak dari lingkungan keluarga, terutama dari kedua orang tua mereka. Sri Lestari (2016) mengatakan bahwa keluarga merupakan unsur yang amat penting bagi seorang anak, terutama kedua orangtua sebagai figur utama dan role model bagi mereka. Hubungan yang terjalin antara anak dengan orangtua menjadi suatu hal yang penting karena merupakan sumber emosional dan kognitif bagi anak. Kondisi tersebut berkaitan dengan kelekatan antara keduanya. Namun pada kenyataannya, beberapa anak dihadapkan pada kenyataan yang sulit bahwa dirinya harus berpisah dengan keluarga mereka karena suatu alasan. Anak-anak tersebut harus menjadi anak yatim, piatu, atau yatim piatu, dan mayoritas disebabkan karena ketidakmampuan keluarga dalam memenuhi kebutuhan jasmani, rohani maupun sosial anak (Ike Oktyanti, 2017). Melihat kenyataan tersebut, berbeda dengan anak yang bisa mendapatkan rasa aman dan nyaman dari kelekatan yang dibangun oleh 
orang tua mereka. Anak yang tinggal di lembaga kesejahteraan sosial anak tentu tidak dapat merasakan rasa aman dan nyaman dari kelekatan yang di bangun oleh orang tua kandungnya (Eka Ervika, 2005).

Pemerintah melalui Kementerian Sosial menyediakan sarana untuk menampung anakanak tersebut, yaitu pengasuhan di dalam Lembaga Kesejahteraan Sosial Anak (LKSA). LKSA berperan dalam membesarkan, mengasuh, mendidik dan memenuhi kebutuhan-kebutuhan mereka termasuk halnya kebutuhan akan kelekatan. Lembaga Kesejahteraan Sosial Anak (LKSA) menjadi pilihan terakhir sebagai sarana pelayanan pengasuhan alternatif untuk anak yang tidak bisa diasuh di dalam keluarga inti, keluarga besar, kerabat, atau keluarga pengganti. Menurut data dari Badan Pusat Statistika (BPS) Provinsi Jawa Barat pada tahun 2016, jumlah anak terlantar sebanyak 135.757, sedangkan di Kabupaten Bandung Barat sendiri sebanyak 2.842 anak. Berdasarkan data dari Dinas Sosial Kabupaten Bandung Barat, pada tahun 2017, terdapat 1.024 anak asuh yang tinggal di dalam LKSA yang tersebar di seluruh wilayah Kabupaten Bandung Barat. Apabila melihat data tersebut maka jumlah anak terlantar cukup besar.

Menurut Peraturan Menteri Sosial Nomor 30 Tahun 2011 tentang Standar Nasional Pengasuhan Anak (SNPA) untuk LKSA, anakanak yang tinggal di LKSA, diasuh oleh pengasuh yang merupakan pengganti figur orangtua. Figur lekat anak akan bergeser kepada pengasuh di LKSA, sebab orang yang paling banyak mengasuh dan dekat dengan keseharian anak adalah pengasuh. Pengasuh merupakan orang yang paling sering berhubungan dan berinteraksi dengan anak yang bermaksud mendidik serta membesarkan mereka. Rasa aman dan nyaman yang berasal dari kualitas kelekatan yang terjalin, masih bisa anak-anak dapatkan dari pengasuh panti (Eka Ervika, 2005). Kelekatan dapat berkembang sesuai dengan perasaan dan perilaku anak dalam kehidupannya. Anak pada awalnya memiliki figur lekat satu orang biasanya adalah ibu, dan seiring dengan bertambahnya usia anak maka figur lekatnya bertambah dengan orang-orang tertentu yang dekat dengan kehidupannya (Christiana Hari Soetjiningsih, 2012).

Pengasuh harus mampu menciptakan kelekatan yang aman (secure attachment) kepada anak-anak asuh di LKSA, termasuk anak asuh yang dari usia bayi sudah tinggal di dalam LKSA. Anak asuh yang dari usia bayi sudah berada di LKSA tidak pernah mengetahui siapa kedua orangtuanya atau bahkan menjalin kelekatan dengan keduanya, sudah jelas peran pengasuh disini sangat penting. Pengasuh diharapkan mampu menjadi figur lekat dengan memberikan kasih sayang, dukungan emosional dan menjadi sumber pemberi rasa aman bagi anak, agar terbangun kualitas kelekatan yang baik (Eka Ervika, 2005). Menurut Peraturan Menteri Sosial Nomor 30 Tahun 2011 tentang Standar Nasional Pengasuhan Anak untuk LKSA, tujuan pengasuhan melalui LKSA adalah diprioritaskan untuk menyediakan lingkungan yang dapat memenuhi kebutuhan kasih sayang, kelekatan (attachment), dan permanensi melalui keluarga pengganti. Maka dari itu, untuk mewujudkan tujuan dari pengasuhan melalui LKSA, dihadirkan sosok pengasuh di dalam LKSA. Namun pada kenyataannya, masih banyak Lembaga Kesejahteraan Sosial Anak yang tidak memenuhi standar dalam hal pemenuhan akan sosok pengasuh di dalam LKSA. Kondisi tersebut mempengaruhi 
kualitas kelekatan yang terjalin antara anak dengan pengasuh panti (Freddy Alhusaini, 2017).

Lembaga Kesejahteraan Sosial Anak Al Kautsar Lembang Kabupaten Bandung Barat, merupakan salah satu sistem pengasuhan alternatif yang memberikan pelayanan pengasuhan kepada anak. LKSA AL Kautsar berlokasi di Jalan Mutiara Utama No. 176 RT 04 RW 05, Desa Lembang, Kecamatan Lembang, Kabupaten Bandung Barat. LKSA ini menjadi lokasi penelitian peneliti untuk mengukur kualitas kelekatan anak dengan pengasuh. Penulis mengambil lokasi penelitian ini dengan alasan karena ditemukan beberapa masalah yang berkaitan dengan kualitas hubungan kelekatan antara anak dan pengasuh. Berdasarkan hasil penjajagan awal, menurut penuturan salah satu pengurus LKSA, LKSA Al Kautsar hanya memiliki empat pengasuh dan sembilan orang pengurus. Para pengurus dan pengasuh tersebut tidak semuanya bermukim menetap di LKSA, namun yang tinggal menetap hanya dua orang, satu orang pengasuh dan satu orang lagi pengurus. Kondisi tersebut menyebabkan pengasuh tidak dapat mengawasi dan menjalin kedekatan dengan anak selama dua puluh empat jam. Selain berperan sebagai pengasuh, pengasuh juga merangkap tugas lainnya di LKSA sehingga fokus perhatiannya terbagi-bagi.

Menurut data Profil LKSA AL Kautsar, jumlah anak asuh yang tinggal di LKSA Al Kautsar berjumlah 58 anak dengan rentang usia 4-18 tahun. Anak-anak asuh mempunyai latar belakang berbeda-beda, ada yang merupakan anak yatim, piatu, yatim piatu dan dhuafa. Berdasarkan kondisi tersebut, bisa dilihat bahwasanya rasio antara jumlah pengasuh dan anak yang diasuh tidak seimbang. Jumlah pengasuh yang hanya 4 orang harus memberikan pengasuhan terhadap anak yang terlampau banyak, akibatnya tidak semua anak asuh mendapatkan perhatian secara optimal (individual). Padahal berdasarkan Peraturan Menteri Sosial Nomor 30 Tahun 2011 tentang Standar Nasional Pengasuhan Anak untuk LKSA, dijelaskan bahwa setiap anak harus memiliki satu pengasuh tetap yang dapat ditemui anak setiap saat dan memberikan perhatian secara individual. Maka dari itu, kondisi tersebut tidak memenuhi standar yang seharusnya dan mempengaruhi kualitas hubungan yang terjalin diantara anak dan pengasuh, karena hubungan tersebut merupakan kunci terciptanya kelekatan diantara keduanya. Menurut penuturan beberapa anak asuh di LKSA Al Kautsar, kondisi yang sering dikeluhkan oleh mereka yaitu perihal peraturan (tata tertib) yang diterapkan di LKSA bisa dikatakan sangat ketat. Walaupun itu semua demi kebaikan dan kepentingan terbaik anak, namun untuk beberapa anak, hal tersebut membuat mereka cenderung tidak terbuka dan merasa takut kepada pengasuh. Selain itu, anak-anak asuh disana mempunyai kegiatan yang padat, yaitu dimulai dari kegiatan sekolah beserta ekstrakurikulernya yang mengharuskan mereka pulang ke panti sore hari. Kondisi tersebut menyebabkan intensitas pertemuan antara anak dan pengasuh menjadi sedikit, tentu komunikasi serta interaksi yang ada juga menjadi terbatas.

Beberapa kondisi yang sudah dijelaskan sebelumnya, tentulah berpengaruh terhadap kualitas kelekatan yang terjalin antara anak dengan pengasuh. Menurut Bowlby dalam Farrington (2005) bahwa kelekatan (attahment) aman yang diperoleh anak merupakan fondasi untuk terbentuknya kemandirian dan membimbing anak dalam berhubungan dengan 
orang lain di masa depan. Maka dari itu, kualitas kelekatan antara anak dengan pengasuh menjadi suatu hal yang penting. Alasan lain yaitu karena belum adanya penelitian yang dilakukan di LKSA ini terkait kualitas kelekatan antara anak dengan pengasuh, ditambah lagi LKSA AL Kautsar merupakan salah satu dari 6 LKSA di Kabupaten Bandung Barat yang sudah terlebih dahulu terakreditasi A pada tahun 2018 oleh Kementerian Sosial Republik Indonesia.

Berdasarkan data yang ada, serta dikaitkan dengan uraian mengenai anak, pengasuhan alternatif, pengasuh, dan kelekatan, maka penulis tertarik untuk melakukan penelitian mengenai "Aspek kehangatan dan kepercayaan dalam kualitas kelekatan anak dengan pengasuh di Lembaga Kesejahteraan Sosial Anak Al Kautsar Lembang Kabupaten Bandung Barat". Penelitian ini bertujuan untuk mendapatkan gambaran tentang kualitas kelekatan anak dengan pengasuh dilihat dari aspek kehangatan dan kepercayaan di dalam Lembaga Kesejahteraan Sosial Anak Al Kautsar Lembang Kabupaten Bandung Barat.

Berdasarkan latar belakang, rumusan masalah dalam penelitian ini adalah "Bagaimana kualitas kelekatan anak dengan pengasuh dilihat dari aspek kehangatan dan kepercayaan di Lembaga Kesejahteraan Sosial Anak Al Kautsar Lembang Kabupaten Bandung Barat?" dengan sub problematik "Bagaimana kehangatan (warmth) anak dengan pengasuh? dan "Bagaimana kepercayaan (trust) anak dengan pengasuh?”. Tujuan penelitian adalah untuk mengetahui gambaran kualitas kelekatan yang terjadi antara anak dengan pengasuh dilihat dari aspek kehangatan dan kepercayaan di Lembaga Kesejahteraan Sosial
Anak Al Kautsar Lembang Kabupaten Bandung Barat.

\section{METODE}

Metode penelitian yang digunakan dalam penelitian ini adalah metode kuantitatif dengan pendekatan deskriptif. Populasi dalam penelitian ini adalah keseluruhan anak asuh penghuni Lembaga Kesejahteraan Sosial Anak Al Kautsar Lembang Kabupaten Bandung Barat, yaitu sebanyak 38 anak, berusia 12-17 tahun. Penulis menetapkan populasi tersebut dengan pertimbangan teori John Piaget tentang Tahap-Tahap Perkembangan Kognitif. Menurut John Piaget dalam Paul Suparno (2001) mengatakan bahwa anak dengan rentang usia 12-17 tahun termasuk dalam Tahap Operasional Formal, yaitu tahap dimana anak sudah mampu berpikir secara abstrak dan logis. Anak sudah mampu menarik kesimpulan tentang suatu hal serta memberikan penafsiran dan mengembangkan hipotesa yang ada. Maka dari itu, anak asuh dengan rentang usia tersebut diharapkan sudah mampu memberikan penilaian dan pertimbangan tentang bagaimana kualitas kelekatan diantara dirinya dan pengasuhnya. Sedangkan untuk teknik penarikan sampel yang digunakan yaitu sampling jenuh (sensus). Teknik sampling jenuh (sensus) digunakan karena jumlah populasinya hanya sebanyak 38 responden yang sudah memenuhi syarat, maka dari itu sampel yang digunakan dalam penelitian ini adalah mengambil keseluruhan dari banyaknya populasi tersebut.

Teknik pengumpulan data yang digunakan adalah kuesioner (angket), wawancara tidak terstruktur, observasi non partisipatif dan studi dokumentasi. Penelitian ini menggunakan skala pengukuran yaitu skala likert. Kemudian Uji validitas yang digunakan 
adalah validitas muka (Face Validity). kuantitatif ini adalah statistik deskriptif. Selanjutnya uji reliabilitas dengan perhitungan Analisa data terdiri dari tahapan editing, Alpha Cronbach, dan dilakukan dengan mengkodekan data, membuat tabulasi, menggunakan aplikasi SPSS 22.0 perhitungan, interpretasi data dan penarikan menunjukkan alpha sebesar 0.973. Teknik kesimpulan.

analisa data yang digunakan dalam penelitian

\section{HASIL PENELITIAN}

\section{Kehangatan}

Kehangatan (warmth) didefinisikan sebagai bentuk keterlibatan orang tua atau pengganti figur orang tua dalam aktivitas anak, kepedulian dan perhatian serta penghargaan dan antusiasme terhadap tingkah laku positif yang ditampilkan oleh anak. Aspek ini terdiri dari 10 (sepuluh) item pernyataan, berikut adalah rekapitulasi hasil penelitian dari setiap item pernyataannya, yaitu :

Tabel 1. Rekapitulasi aspek kehangatan (warmth) anak dengan pengasuh

\begin{tabular}{|c|c|c|c|c|c|}
\hline No & Pernyataan & $\begin{array}{c}\text { Skor } \\
\text { Aktual } \\
\end{array}$ & $\begin{array}{l}\text { Skor } \\
\text { Ideal }\end{array}$ & $(\%)$ & $\begin{array}{l}\text { Kategori } \\
\text { Skor }\end{array}$ \\
\hline 1. & $\begin{array}{l}\text { Pengasuh memberikan } \\
\text { ucapan selamat apabila saya } \\
\text { mampu berprestasi di } \\
\text { sekolah. }\end{array}$ & 118 & 152 & 77.63 & Tinggi \\
\hline 2. & $\begin{array}{l}\text { Pengasuh menyemangati } \\
\text { saya ketika saya } \\
\text { menghadapi ujian. }\end{array}$ & 122 & 152 & 80.26 & Tinggi \\
\hline 3. & $\begin{array}{l}\text { Pengasuh meluangkan } \\
\text { waktu untuk menemani saya } \\
\text { belajar. }\end{array}$ & 91 & 152 & 59.87 & Sedang \\
\hline 4. & $\begin{array}{l}\text { Pengasuh selalu } \\
\text { menanyakan kabar saya. }\end{array}$ & 98 & 152 & 64.47 & Sedang \\
\hline 5. & $\begin{array}{l}\text { Pengasuh memuji saya, } \\
\text { apabila saya melakukan } \\
\text { sikap positif. }\end{array}$ & 110 & 152 & 72.37 & Sedang \\
\hline 6. & $\begin{array}{ll}\text { Pengasuh } & \text { selalu } \\
\text { mengingatkan saya } & \text { untuk } \\
\text { melaksanakan sholat. } & \\
\end{array}$ & 131 & 152 & 86.18 & Tinggi \\
\hline 7. & $\begin{array}{l}\text { Pengasuh tidak pernah } \\
\text { menyempatkan mengobrol } \\
\text { dengan saya. }\end{array}$ & 104 & 152 & 68.42 & Sedang \\
\hline 8. & $\begin{array}{l}\text { Pengasuh tidak pernah } \\
\text { menemani saya makan. }\end{array}$ & 101 & 152 & 66.44 & Sedang \\
\hline 9. & $\begin{array}{l}\text { Pengasuh tidak pernah } \\
\text { mengingatkan saya untuk } \\
\text { mengerjakan tugas-dari } \\
\text { sekolah. }\end{array}$ & 107 & 152 & 70.39 & Sedang \\
\hline 10. & $\begin{array}{l}\text { Pengasuh tidak pernah } \\
\text { memperhatikan kebersihan } \\
\text { diri saya. }\end{array}$ & 116 & 152 & 76.31 & Tinggi \\
\hline & Jumlah & 1098 & 1520 & 72.23 & Sedang \\
\hline
\end{tabular}

Berdasarkan hasil rekapitulasi pada aspek kehangatan (warmth) pada Tabel 1 dapat diketahui bahwa jumlah keseluruhan skor aktual yang didapatkan dari aspek kehangatan (warmth) anak dengan pengasuh yaitu 1098. Jumlah skor aktual tersebut akan 
digunakan dalam menentukan kategori untuk aspek kehangatan (warmth) anak dengan pengasuh pada garis kontinum.
Adapun perhitungan untuk menentukan kategori tersebut pada garis kontinum, adalah sebagai berikut :

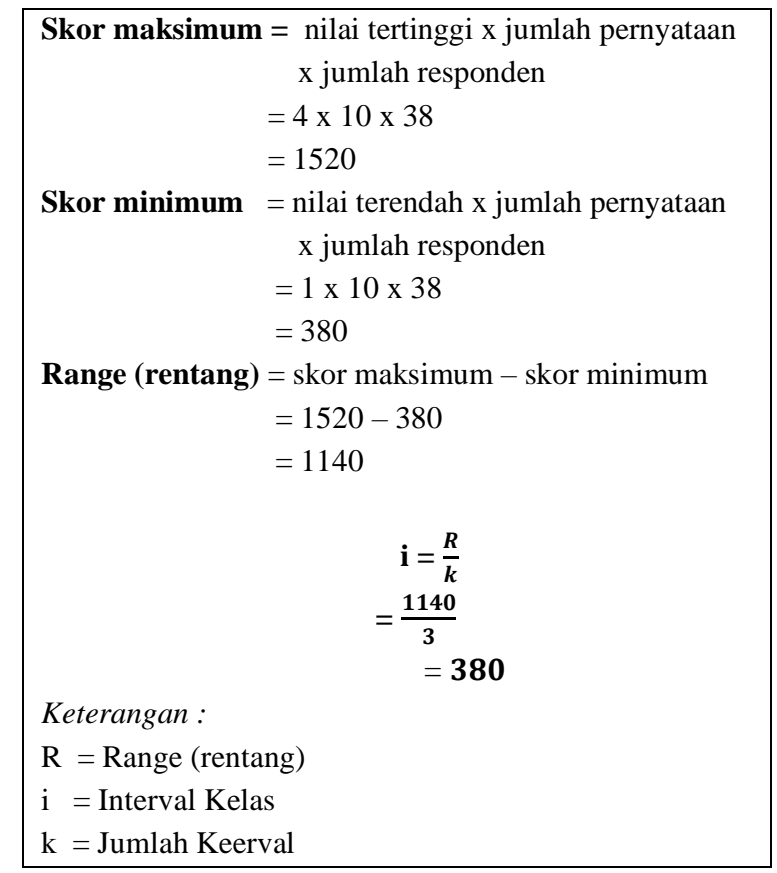

Gambar 1. Rumus perhitungan batas skor aspek kehangatan (warmth)

$$
\begin{aligned}
\text { Rendah } & =380-760 \\
\text { Sedang } & =761-1140 \\
\text { Tinggi } & =1141-1520
\end{aligned}
$$

Gambar 2. Batas skor garis kontinum aspek kehangatan (warmth)

Selanjutnya, gambaran aspek kehangatan jumlah skor aktual 1098, apabila dilihat pada (warmth) anak dengan pengasuh dengan garis kontinum yaitu sebagai berikut :

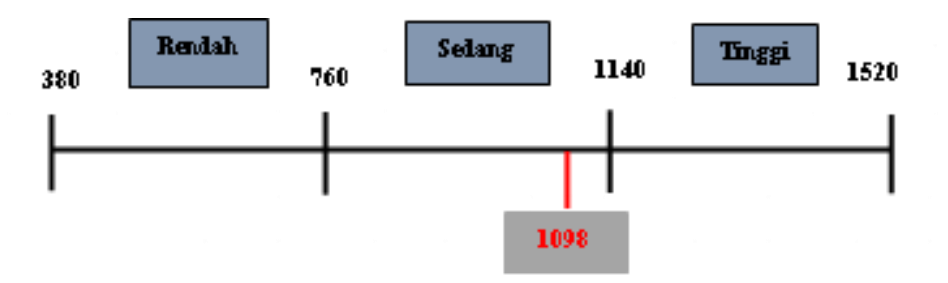

Gambar 3. Garis kontinum aspek kehangatan (warmth) 
Gambar 3 menunjukkan bahwa kualitas kelekatan anak dengan pengasuh di Lembaga Kesejahteraan Sosial Anak Al Kautsar Lembang Kabupaten Bandung

\section{Kepercayaan (Trust)}

Kepercayaan (trust) didefinisikan sebagai suatu keyakinan yang dimiliki seorang anak bahwa figur lekatnya akan membantu dan memberikan apa yang mereka harapkan dan butuhkan, bisa dilihat juga dari bagaimana
Barat pada aspek kehangatan (warmth), dengan total skor sebesar 1098 termasuk dalam kategori sedang.

keterbukaan anak terhadap figur lekatnya. Aspek ini terdiri dari 10 (sepuluh) item pernyataan, berikut adalah rekapitulasi hasil penelitian.

Tabel 2. Rekapitulasi aspek kepercayaan (trust) anak dengan pengasuh

\begin{tabular}{|c|c|c|c|c|c|}
\hline No & Pernyataan & $\begin{array}{c}\text { Skor } \\
\text { Aktual }\end{array}$ & $\begin{array}{l}\text { Skor } \\
\text { Ideal }\end{array}$ & $(\%)$ & $\begin{array}{l}\text { Kategori } \\
\text { Skor }\end{array}$ \\
\hline 1. & $\begin{array}{l}\text { Pengasuh menerima saya } \\
\text { apa adanya. }\end{array}$ & 118 & 152 & 77.63 & Tinggi \\
\hline 2. & $\begin{array}{l}\text { Pengasuh menghargai } \\
\text { perasaan saya. }\end{array}$ & 99 & 152 & 65.13 & Sedang \\
\hline 3. & $\begin{array}{l}\text { Saya percaya pengasuh } \\
\text { selalu memberikan yang } \\
\text { terbaik untuk saya. }\end{array}$ & 111 & 152 & 73.02 & Sedang \\
\hline 4. & $\begin{array}{l}\text { Saya berharap pengasuh } \\
\text { saya yang sekarang } \\
\text { digantikan oleh pengasuh } \\
\text { yang lain. }\end{array}$ & 97 & 152 & 63.81 & Sedang \\
\hline 5. & $\begin{array}{l}\text { Pengasuh saya percaya } \\
\text { kalau saya akan menjadi } \\
\text { orang yang lebih baik di } \\
\text { masa yang akan datang. }\end{array}$ & 121 & 152 & 79.60 & Tinggi \\
\hline 6. & $\begin{array}{l}\text { Saya percaya kepada } \\
\text { pengasuh sehingga apapun } \\
\text { akan saya ceritakan } \\
\text { kepada beliau. }\end{array}$ & 91 & 152 & 59.86 & Sedang \\
\hline 7. & \begin{tabular}{lrr} 
Pengasuh & \multicolumn{1}{c}{ saya } & hanya \\
sekedar & menjalankan \\
tugasnya & sebagai \\
pengasuh LKSA. & \\
\end{tabular} & 85 & 152 & 55.92 & Sedang \\
\hline 8. & $\begin{array}{l}\text { Pengasuh percaya bahwa } \\
\text { saya bisa bersikap baik } \\
\text { dimanapun saya berada. }\end{array}$ & 114 & 152 & 75.00 & Sedang \\
\hline 9. & $\begin{array}{lr}\text { Pengasuh tidak } & \text { pernah } \\
\text { memberikan } & \text { saya } \\
\text { kesempatan } & \text { untuk } \\
\text { menjelaskan } & \text { mengenai } \\
\text { apapun. } & \\
\end{array}$ & 94 & 152 & 61.84 & Sedang \\
\hline 10. & $\begin{array}{l}\text { Pengasuh saya tidak } \\
\text { mempercayai pendapat } \\
\text { saya. }\end{array}$ & 106 & 152 & 69.73 & Sedang \\
\hline & Jumlah & 1036 & 1520 & 68.15 & Sedang \\
\hline
\end{tabular}

Berdasarkan hasil rekapitulasi pada aspek kepercayaan (trust) anak dengan pengasuh pada Tabel 2 dapat diketahui bahwa skor tertinggi yang didapatkan ada pada item pernyatataan nomor lima dengan jumlah skor total sebesar 121 dan masuk dalam kategori tinggi. Sedangkan untuk skor terendah yaitu ada pada item pernyataan 
nomor tujuh dengan jumlah skor sebesar 85 dan masuk dalam kategori sedang. Kemudian, dapat dilihat juga dalam Tabel 2 bahwa jumlah skor aktual yang didapatkan dari aspek kepercayaan (trust) anak dengan pengasuh yaitu 1036. Jumlah skor aktual tersebut akan digunakan dalam menentukan kategori untuk aspek kepercayaan (trust) anak dengan pengasuh pada garis kontinum. Adapun perhitungannya adalah sebagai berikut:

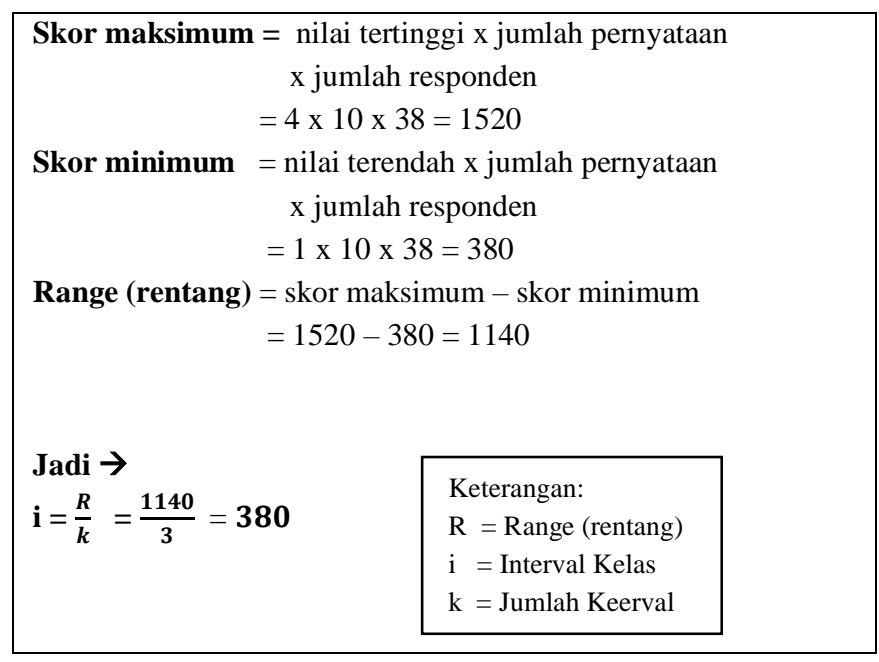

Gambar 4. Rumus perhitungan batas skor garis kontinum aspek kepercayaan

$$
\begin{aligned}
\text { Rendah } & =380-760 \\
\text { Sedang } & =761-1140 \\
\text { Tinggi } & =1141-1520
\end{aligned}
$$

Gambar 5: Rumus perhitungan batas skor aspek kepercayaan (trust)

Selanjutnya, gambaran aspek kepercayaan (trust) anak dengan pengasuh dengan jumlah skor aktual 1036, apabila dilihat pada garis kontinum yaitu sebagai berikut :

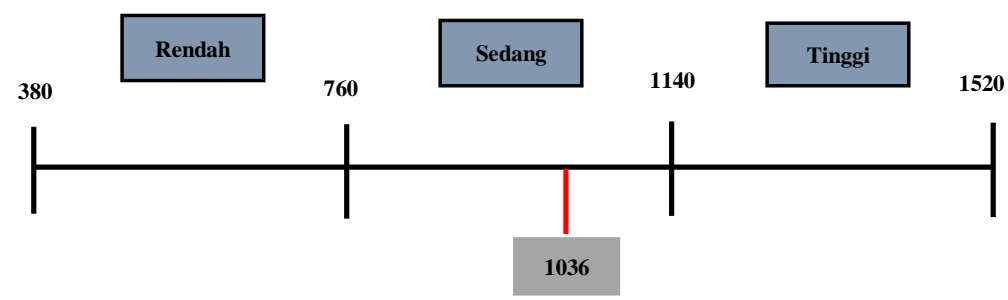

Gambar 6: Garis kontinum aspek kepercayaan (trust) 
Berdasarkan Gambar 6 dapat dilihat bahwa kualitas kelekatan (atachment) anak dengan pengasuh di Lembaga Kesejahteraan Sosial Anak Al Kautsar Lembang pada aspek kepercayaan (trust), dengan jumlah skor aktual sebesar 1036, maka tergolong termasuk dalam kategori sedang.

\section{PEMBAHASAN}

\section{Kehangatan}

Analisa masalah dalam aspek kehangatan yaitu perilaku hangat yang ditampilkan dalam hubungan kelekatan diantara anak dan pengasuh di LKSA Al Kautsar tercermin dari keikutsertaan pengasuh di dalam aktivitas sehari-hari bersama dengan anak, seperti halnya pengasuh yang meluangkan waktunya untuk sekedar menemani anak makan. Kondisi tersebut sesuai dengan pendapat yang dikemukakan oleh Broderick \& Blewitt dalam Rodriguez, dkk. (2009) bahwa aspek kehangatan menyiratkan tentang keterlibatan dan ketertarikan seseorang dalam aktivitas yang dilakukan oleh anak. Selain itu, aspek kehangatan juga terwujud dari perhatian pengasuh terhadap kebutuhan dan kondisi anak, seperti halnya pengasuh yang selalu mengingatkan anak untuk menunaikan sholat. Kondisi tersebut sesuai dengan pendapat dari Yusuf Efendi (2010) mengatakan bahwa salah satu bentuk dari kehangatan figur lekat adalah dengan perhatian terhadap kesejahteraan anak. Kemudian tergambarkan juga pada penghargaan yang diberikan pengasuh kepada anak atas perilaku positif yang ditampilkan oleh mereka, misalkan saja pengasuh yang memberikan ucapan selamat atas keberhasilan apabila anak mampu berprestasi di sekolahnya.
Selanjutnya, berdasarkan keseluruhan jawaban responden menggambarkan bahwa kualitas kelekatan yang terjalin antara pengasuh dan anak di LKSA Al Kautsar dalam aspek kehangatan cukup mempunyai hubungan yang hangat. Namun dari jawaban responden juga, menggambarkan bahwa aspek kehangatan dari pengasuh belum merata diberikan kepada seluruh anak asuh yang ada, sehingga sebagian anak mengaku kurang merasakan kehangatan dari sosok pengasuh yang merawat mereka. Maka dari itu diperlukan adanya upaya nyata untuk meningkatkan kualitas kelekatan yang dilihat dari aspek kehangatan, agar lebih maksimal atau agar mencapai skor yang lebih tinggi.

Berdasarkan analisa permasalahan pada aspek kehangatan di atas, berikut analisa kebutuhannya yang mana berkaitan dengan kurangnya kualitas kelekatan yang dilihat dari aspek kehangatan, yaitu lebih tepatnya permasalahan kurangnya keterlibatan pengasuh dalam aktivitas yang dilakukan oleh anak serta pengasuh yang kurang mengetahui kegiatan-kegiatan yang diikuti oleh anak di luar LKSA, yang mana dapat menjadi penyebab munculnya masalahmasalah lainnya. Kebutuhan berkaitan dengan hal tersebut yaitu peningkatan kontrol serta pemantauan dari pengasuh. Menurut Sri Lestari (2016), kontrol dan juga pemantauan merupakan salah satu dimensi pengasuhan yang seharusnya ada di dalam hubungan kelekatan antara anak dengan figur orang tua mereka, dalam hal ini digantikan oleh pengasuh.

Kontrol dan pemantauan yang dimaksud disini adalah dalam pengertian yang positif. Kontrol disini bisa dengan kontrol secara psikologis atau kontrol secara perilaku. 
Sedangkan bentuk pemantauan yang bisa diberikan pengasuh adalah dengan terlibat dan memberikan dukungan atas aktivitasaktivitas yang dilakukan anak. Menurut Waizenhofer dkk dalam Sri Lestari (2016) membedakan bentuk pemantauan yang diberikan orang tua bisa dilakukan dengan dua cara, yaitu dengan menanyakan langsung kepada anak atau ikut berpartisipasi dalam aktivitas anak. Kemudian yang kedua adalah dengan mengetahui aktivitas rutin atau mendapatkan informasi dari orang lain tanpa menanyakan kenapa anak secara langsung. Pemantauan dari pengasuh di LKSA Al Kautsar bisa dilakukan dengan dua cara seperti diatas, bisa dengan meningkatkan keterlibatan dalam aktivitas anak atau menanyakan secara langsung dan bisa dengan menanyakan kepada orang lain yaitu kepada anak asuh lain yang dekat dengan anak tersebut. Kontrol dan pemantauan yang optimal dari pengasuh akan meningkatkan kedekatan antara anak dengan pengasuh, sehingga kualitas kelekatan anak dengan pengasuh juga meningkat.

Selain kebutuhan pada aspek kehangatan di atas, terdapat satu lagi kebutuhan yang dirasa harus dipenuhi yaitu kebutuhan adanya peningkatan pemahaman para pengasuh tentang bagaimana memberikan pengasuhan yang terbaik untuk anak-anak asuh, sesuai dengan standar nasional pengasuhan anak untuk LKSA. Karena diharapkan ketika pengasuh lebih tahu dan faham tentang pengasuhan, bagaimana cara mengasuh, merawat dan mendidik anak, kualitas kelekatan yang terbangun juga akan lebih baik. Peningkatan pemahaman dan penerapan SNPA yang dimaksud adalah bisa dengan memberikan pelatihan kepada para pengasuh tentang bagaimana memberikan pengasuhan agar tercipta kualitas kelekatan yang baik antara anak dengan pengasuh sebagai figur pengganti orangtua

\section{Kepercayaan}

Analisa masalah dalam aspek kepercayaan yaitu berkaitan dengan keyakinan yang dimiliki seorang anak bahwa figur lekatnya akan membantu dan memberikan apa yang mereka harapkan dan butuhkan, bisa dilihat juga dari bagaimana keterbukaan anak terhadap figur lekatnya. Penerapannya antara lain ketika pengasuh yang percaya jikalau nantinya anak akan menjadi orang yang lebih baik di masa depan, kondisi tersebut menggambarkan bahwa pengasuh mampu menanamkan kepercayaannya kepada anak asuh, bahwa mereka akan bisa menjadi lebih baik dan sukses di masa depan. Karena ketika pengasuh mampu percaya dengan anak, begitupun sebaliknya, akan tertanam pula kepercayaan dalam diri anak kepada pengasuh. Sehingga anakpun akan berusaha memberikan yang terbaik. Kondisi tersebut juga sesuai dengan pendapat dari Eka Ervika (2005) yang mengatakan bahwa apabila figur lekat menghadirkan hubungan yang membuat anak tidak percaya dengan sosok figur lekat, maka anak akan tumbuh menjadi pribadi yang kesulitan berhubungan dengan orang lain dan tidak mempercayai mereka. Selain itu, kondisi tersebut juga diperkuat dengan hasil wawancara tidak terstruktur penulis dengan responden, bahwa beberapa dari mereka yang mempunyai anggapan bahwa sebenarnya pengasuh mereka hanya sekedar menjalankan tugasnya sebagai pengasuh. Mereka kadangkala merasakan kondisi itu pada saat-saat tertentu, misalkan ketika pengasuh bersikap kurang baik kepada 
mereka, yaitu lebih sering marah-marah atau membentak-bentak mereka.

Selanjutnya berdasarkan hasil dari keseluruhan jawaban responden, menggambarkan bahwa kualitas kelekatan anak dengan pengasuh di LKSA Al Kautsar dalam aspek kepercayaan sudah berdasar pada rasa percaya. Bentuk kepercayaan yang ditampilkan antara lain, pengasuh yang percaya kepada anak bahwa mereka dapat bersikap baik tidak hanya ketika di depan pengasuh, namun ketika dimanapun mereka berada, kemudian pengasuh yang percaya bahwa anak nantinya dapat menjadi seorang yang sukses dan anak yang merasa bahwa pengasuh mampu menerima dirinya dengan apa adanya. Namun dari jawaban responden juga, menggambarkan bahwa aspek kepercayaan dari pengasuh belum merata diberikan kepada seluruh anak asuh yang ada, sehingga sebagian anak mengaku kurang merasakan adanya rasa saling percaya antara mereka dengan pengasuh. Maka dari itu, perlu adanya upaya nyata untuk meningkatkan kualitas kelekatan yang dilihat dari aspek kepercayaan, agar lebih maksimal atau agar mencapai skor yang lebih tinggi.

Berdasarkan Analisa permasalahan pada aspek kepercayaan di atas, berikut analisa kebutuhannya yaitu berkaitan dengan kurangnya kualitas kelekatan yang dilihat dari aspek kepercayaan, kondisi tersebut menyebabkan kurangnya keterbukaan antara anak dengan pengasuh, Maka dari itu kebutuhan yang dimaksudkan adalah adanya peningkatan keterbukaan antara anak dengan pengasuh, Karena ketika anak maupun pengasuh saling terbuka satu sama lain, kepercayaan itu akan muncul dengan sendirinya. Misalnya saja ketika anak bersedia menceritakan permasalahannya kepada pengasuh, itu menandakan bahwa anak percaya dengan sosok pengasuh mereka. Maka dari itu, apabila keterbukaan tersebut sudah terbangun, hubungan antara anak dengan pengasuhpun juga akan membaik dan diharapkan kualitas kelekatan juga akan semakin tinggi/baik.

Kemudian. secara keseluruhan kualitas kelekatan anak dengan pengasuh di Lembaga Kesejahteraan Sosial Anak Al Kautsar Lembang Kabupaten Bandung Barat, termasuk dalam kategori sedang. Kondisi tersebut karena dipengaruhi oleh beberapa faktor seperti halnya masih terdapat unsur kekerasan dari pengasuh terhadap anak. Kekerasan tersebut dilakukan baik secara emosional yaitu dengan pengasuh yang masih sering marah-marah dan membentak anak, serta secara fisik yaitu dengan mencubit maupun memukul walaupun intensitasnya tidak sering. Sistem Pendidikan yang konvensional yang seringkali menggunakan cara hukuman (baik fisik maupun emosional) untuk mendidik dan mendisiplinkan anak, pengasuh yang cenderung menjaga jarak dan bahkan ada yang sengaja membangun image menakutkan agar anak hormat dan patuh pada mereka. Padahal cara tersebut justru akan membuat anak tumbuh menjadi pribadi yang penakut, mudah berkecil hati dan tidak percaya diri.

Selain itu, faktor lain yang mempengaruhi adalah karena kurang konsistennya cara pengasuhan yang dilakukan oleh pengasuh, sikap pengasuh yang kurang dapat diprediksi seperti halnya pengasuh yang kadangkala bersifat manis, tiba-tiba bisa berubah drastis dengan mudah marah, membuat anak menjadi bingung, tidak yakin 
dan sukup sulit mempercayai dan patuh pada pengasuh mereka. Kedua faktor tersebut diperkuat dengan hasil wawancara tidak terstruktur kepada responden anak asuh yang menyatakan hal serupa, kemudian didukung juga dengan teori dari Erickson dalam Yusuf Efendi (2010) yang mengatakan bahwa ada beberapa faktor yang dapat menyebabkan gangguan pada kelekatan, yaitu antara lain adalah adanya kekerasan secara psikis maupun fisik dan tidak konsistennya cara pengasuhan yang diberikan oleh figur lekat. Kualitas kelekatan anak dengan pengasuh di Lembaga Kesejahteraan Sosial Anak (LKSA) Al Kautsar berada dalam kategori sedang yang dimaksudkan disini adalah kecenderungan anak yang kurang yakin bahwa figur lekat yaitu pengasuh mereka akan selalu ada untuk mereka. Karena rasa kurang yakin ini, anak mudah mengalami kecemasan untuk berpisah. Dalam diri anak muncul ketidakpastian, karena pengasuh tidak selalu ada, serta terdapat jarak diantara mereka. Kondisi tersebut terjadi diakibatkan karena respon atau ketersediaan yang tidak konsisten dari pengasuhnya, kadang ada, kadang tidak, kadang baik, kadang marahmarah. Kualitas kelekatan anak dengan pengasuh di LKSA Al Kautsar dalam kategori sedang cenderung termasuk dalam Pola Resistant Attachment (Ambivalen).

Kemudian, selain analisa masalah serta kebutuhan, terdapat juga Analisa sistem sumber yang dapat dimanfaatkan untuk upaya peningkatan. Beikut ini adalah uraian analisa sistem sumber yang dapat dimanfaatkan oleh anak maupun pengasuh untuk upaya peningkatan: a. Sumber Informal.

Sumber informal sering juga disebut sumber alamiah, bantuan yang diberikan bisa berupa dukungan, nasehat serta kasih sayang dan lain sebagainya. Sumber informal tersebut yaitu: (1) orang tua kandung responden, sumber ini berlaku untuk responden yang masih mempunyai orang tua, baik yang masih lengkap, yatim atau piatu, (2) para pengasuh, keluarga/kerabat dekat responden, (4) pengurus LKSA Al Kautsar, (5) teman sekolah responden, dan (6) teman satu LKSA responden.

b. Sumber Formal

Sumber formal ini bersifat kelembagaan, yaitu berdasarkan keanggotaan dalam suatu lembaga. Sumber formal tersebut, yaitu: (a) Lembaga Kesejahteraan Sosial Anak (LKSA) Al Kautsar Lembang, (b) Yayasan Al Kautsar Indonesia yang menaungi LKSA Al Kautsar Lembang.

\section{c. Sumber Kemasyarakatan}

Sumber kemasyarakatan tersebut, yaitu Dinas Sosial Kabupaten Bandung Barat, yang didalamnya juga terdapat pekerja sosial ataupun tenaga profesional lainnya serta program dan pelayanan lain untuk anak yatim, piatu, yatim piatu atau dhuafa dan anak terlantar lainnya yang dapat membantu memecahkan masalah

\section{KESIMPULAN DAN SARAN}

Aspek kehangatan dan kepercayaan dalam kelekatan anak dengan pengasuh di LKSA Al Kautsar keduanya bersifat sedang, yang mana berarti sudah terbangun kelekatan diantara keduanya walaupun belum secara optimal. Karena kedua aspek dalam kelekatan tersebut merupakan dua hal yang penting dalam membangun kelekatan untuk kehidupan anak 
selanjutnya, antara lain adalah anak mampu menjalin relasi yang positif dengan orang lain.

Aspek kehangatan dan kepercayaan pada kualitas kelekatan yang terjalin antara anak dengan pengasuh di LKSA Al Kautsar berbedabeda. Penelitian ini dilakukan terhadap 38 anak asuh dengan karakteristik usia 12-17 tahun dan tinggal di Lembaga Kesejahteraan Sosial Anak (LKSA) Al Kautsar Lembang Kabupaten Bandung Barat. Berdasarkan hasil penelitian, pada aspek kehangatan 38 responden yang telah memberikan jawaban dari 10 item pernyataan mendapatkan skor aktual sebesar 1098. Kondisi tersebut menggambarkan bahwa kehangatan antara anak dengan pengasuh di LKSA Al Kautsar termasuk dalam kategori sedang, yang berarti cukup hangat. Berdasarkan analisa kebutuhan didapatkan hasil bahwa kebutuhan yang diperlukan untuk mengatasi permasalahan kurangnya kualitas kelekatan anak dengan pengasuh di LKSA Al Kautsar adalah kebutuhan peningkatan kontrol dan pemantauan dari pengasuh serta peningkatan pemahaman dan penerapan Standar Nasional Pengasuhan Anak (SNPA) untuk Lembaga Kesejahteraan Sosial Anak (LKSA). Selanjutnya pada aspek kepercayaan 38 responden yang telah memberikan jawaban dari 10 item pernyataan mendapatkan skor aktual 1036. Kondisi tersebut menggambarkan bahwa kepercayaan antara anak dengan pengasuh di LKSA Al Kautsar termasuk dalam kategori sedang, yang berarti cukup percaya.

Berdasarkan kebutuhan dan dikarenakan aspek kehangatan dan kepercayaan dalam kualitas kelekatan termasuk dalam kategori sedang, maka dari itu penulis merancang program yang bertujuan untuk meningkatkan kualitas kelekatan dengan mengupayakan kedua aspek tersebut agar mencapai skor yang lebih tinggi. Program tersebut adalah Educating and Fun Sharing (EDUFAS) untuk peningkatan kualitas kelekatan anak dengan pengasuh di Lembaga Kesejahteraan Sosial Anak (LKSA) Al Kautsar Lembang Kabupaten Bandung Barat. Program ini telah dianalisis kelayakannya dengan menggunakan metode analisis SWOT dan analisis Pro-Test dan PostTest. Hasil analisis menunjukkan bahwa program tersebut dapat diimplementasikan untuk meningkatkan kualitas kelekatan anak asuh dengan pengasuh di LKSA Al Kautsar Lembang Kabupaten Bandung Barat. Sehingga diharapkan tujuan-tujuan yang telah ditentukan sebelumnya dapat tercapai dengan maksimal.

Saran terkait dengan hasil penelitian ini ditujukan kepada LKSA Al Kautsar Lembang Kabupaten Bandung Barat dan Dinas Sosial Kabupaten Bandung Barat. Untuk kepada LKSA Al Kautsar Lembang Kabupaten Bandung Barat adalah:

1. Agar tetap konsisten dalam melaksanakan program yang sudah direkomendasikan dan terus melakukan inovasi-inovasi baru yang lebih kreatif dan juga lebih efekif dalam pelaksanaannya;

2. Tetap memberikan arahan dan dukungannya kepada para pengasuh agar terus menjalin kedekatan dengan anak, sehingga akan terbangun aspek kehangatan dan kepercayaannya juga dengan sendirinya;

3. Dapat menjaga hubungan/relasi dan tetap melakukan koordinasi dengan berbagai pihak yang terkait;

4. Membenahi penerapan sistem pengasuhan agar lebih sesuai dengan Peraturan Menteri Sosial Republik Indonesia Nomor: 30/HUK/ 2011 tentang Standar Nasional Pengasuhan Anak (SNPA) untuk Lembaga Kesejahteraan Sosial Anak (LKSA), serta 
5. Melakukan perekrutan sumber daya manusia (SDM) untuk pengasuh yang baru, mengingat masih kurangnya jumlah pengasuh yang ada di Lembaga Kesejahteraan Sosial Anak (LKSA) Al Kautsar Lembang.

Adapun saran bagi Dinas Sosial Kabupaten Bandung Barat adalah:

1. Mengadakan kegiatan peningkatan kompetensi dari para pengasuh anak-anak di LKSA melalui kegiatan workshop atau seminar mengenai pengasuhan ataupun tema lain yang berhubungan dengan anak, terutama yang berkaitan dengan kehangatan dan kepercayaan;

2. Memberikan dukungan terhadap program yang telah dilaksanakan dan memberikan stimulus kepada pihak LKSA Al Kautsar Lembang Kabupaten Bandung Barat, agar dapat memberikan inovasi-inovasinya dalam menciptakan kegiatan-kegiatan baru guna meningkatkan aspek kehangatan dan kepercayaan sebagai unsur dari kelekatan, diantara anak-anak asuh dan pengasuh;

3. Melakukan peninjauan dan evaluasi secara rutin dan komprehensif kepada pihak LKSA Al Kautsar Lembang Kabupaten Bandung Barat, serta

4. Mampu meningkatkan koordinasi antar instansi pemerintahan lainnya seperti kepada Dinas Pengendalian Penduduk Keluarga Berencana Pemberdayaan Perempuan dan Perlindungan Anak (DP2KBP3A) Kabupaten Bandung Barat, Pusat Pelayanan Terpadu Pemberdayaan Perempuan dan Anak (P2TP2A) Kabupaten Bandung Barat atau bahkan Komisi Perlindungan Anak Indonesia (KPAI) dalam pelaksanaan program yang direkomendasikan ataupun program lain yang serupa.
Saran terkait dengan penelitian selanjutnya, yaitu :

1. Penelitian selanjutnya dapat memperluas lingkup penelitian dengan cara melakukan penelitian dengan metode kualitatif untuk dapat menggali secara lebih mendalam tentang bagaimana aspek kehangatan dan kepercayaan pada kualitas kelekatan antara anak dengan pengasuh.

2. Penelitian selanjutnya diharapkan dapat meneliti variabel-variabel lain yang mungkin berhubungan dengan aspek kehangatan dan kepercayaan pada kualitas kelekatan anak dengan pengasuh.

3. Penelitian selanjutnya diharapkan dapat melakukan penelitian dengan topik yang serupa, namun pada karakteristik subjek yang berbeda, seperti halnya melakukan penelitian pada remaja karena merupakan masa peralihan dari masa kanak-kanak ke masa dewasa.

\section{DAFTAR PUSTAKA}

Abu Huraerah. (2018). Kekerasan terhadap Anak. Bandung: Nuansa Cendekia.

Christiana Hari Soetjiningsih. (2012). Perkembangan Anak: Sejak Pembuahan Sampai dengan Kanak-Kanak Akhir. Jakarta: Prenada Media Group

Desmita. (2013). Psikologi Perkembangan. Cetakan VIII. Bandung: Remaja Rosdakarya.

Eka Ervika. (2005). Jurnal Psikologi: Kelekatan (Attachment) pada Anak. Medan: Universitas Sumatera Utara.

Geldard, K. \& David, G. (2011). Konseling Remaja. Yogyakarta: Pustaka Pelajar.

Ike Oktyanti. (2017). Attachment Pengasuh dengan Anak Pra Sekolah. Jurnal UIN Sunan Ampel.

Irawan Soehartono. (2015). Metode Penelitian Sosial. Cetakan IX. Bandung: Remaja Rosdakarya.

Moh Nazir. (2017). Metode Penelitian. Cetakan XI. Bogor: Ghalia Indonesia. 
Paul Suparno. (2001). Teori Perkembangan Kognitif Jean Piaget. Yogyakarta: Kanisius

Peraturan Menteri Sosial Nomor 30 Tahun 2011 tentang Standar Nasional Pengasuhan Anak untuk Lembaga Kesejahteraan Sosial Anak Profil Lembaga Kesejahteraan Sosial Anak (LKSA) Al Kautsar Lembang, Kabupaten Bandung Barat

Sri Lestari. (2016). Psikologi Keluarga. Cetakan IV. Jakarta: Prenada Media Group.

Sugiyono. (2017). Metode Penelitian Kuantitatif Kualitatif dan $R \& D$. Cetakan ke25. Bandung: Alfabeta.

Undang-Undang Nomor 35 Tahun 2014 tentang Perubahan Atas Undang-Undang Nomor 23 Tahun 2002 tentang Perlindungan Anak.

Yusuf Efendi. (2010). Psikologi Perkembangan Rentang Kehidupan. Bandung: PT. Remaja Rosdakarya.

\section{Internet}

Badan Pusat Statistika Provinsi Jawa Barat. (2016). Data Jumlah Permasalahan Sosial Menurut Jenis. Diakses dari https:// jabar.bps.go.id/statictable/2018/03/19/405/j umlah- permasalahan-sosial-menurut jenis-di-jawa-barat-2016.html

Freddy Alhusaini. (2017). Skripsi: Kelekatan Anak di Panti Asuhan. Surakarta: Universitas Muhammadiyah Surakarta (UMS). Diakses dari https:// eprints.ums.ac.id/58042/18/Naskah\%20Pub likasi- 205.

Rodriguez, M.M.D., Melissa R. D., Susan L. C. (2009). Parenting Styles in a Cultural Context: Observations of "Protective Parenting" in First-Generation Latinos. Diakses dari https://search.proquest.com/sociology/docv ie/18874594/51885810FD3C4CODPQ/1? a ccountid $=50790$ 